Eloise Govier

\title{
Do You Follow? Rethinking Causality in Archaeology
}

\author{
Abstract \\ Philosopher and Physicist Karen Barad (2003, 2007, 2012) has brought a new understanding of causality \\ to the academic discourse (agential realism theory). Inspired by this new take on causality, I problematise \\ the argument that archaeologists 'follow' materials. I begin by challenging the act of 'following' on two \\ counts (causality and universalism), and then consider the work of Malafouris-a thinker whose ideas have \\ the potential to remediate this issue through his examination of the 'in between' humans and matter \\ (2008c). I argue that, despite offering an inspirational approach to mind-matter relationships, the \\ dialectical relationship he evokes remains problematic from a Baradian perspective as it is still rooted in \\ 'following'. I suggest that Barad's agential realism offers a valuable conceptual framework for \\ researchers who are weary of 'unilateral' (Barad 2007, 214) linear causality and keen to move beyond \\ dialectical thinking.
}

\section{Keywords}

Causality, agential realism, phenomena, following, dialectics, New Materialisms

\section{Introduction}

Anthropologist Tim Ingold argues that humans 'follow' things, he contends that 'knowing is a process of active following, of going along' (2013, 1, see also 2007, 26). Quoting Deleuze and Guattari (2005), Ingold notes 'matter-flow can only be followed' $(2013,25)$. This idea has seeped into and informed archaeological texts; Matt Edgeworth $(2012,76)$ writes that 'Archaeologists follow cuts of features, 
affordances of materials and rhythms of artefacts' $(2012,91)$. Similarly, Christopher Witmore notes that material culture are the things archaeologists start with, and explains that archaeologists 'follow this stuff wherever it may lead' $(2014,205-206,226)$. Also of note, is the work of Mary Weismantel and Lynn Meskell who propose 'following' as a method, arguing that 'following the makers' focus' and following the material substance can aid archaeological interpretation (2014, 235, see also Kersel and Chesson's 'Follow the Pots Project').

When used as a preposition 'following' means 'coming after or as a result of', when used as an adjective it means 'next in time' (Oxford Dictionaries, 2018). Therefore, a linear and progressive causal model is employed when we use the word. New materialist thinker Karen Barad has offered a new conceptual approach to causality which contends that causes and effects emerge in-phenomena rather than through 'unilateral' movements from causes to effects $(2007,214)$. Undeniably, the causal link between archaeologist and material ('we follow') sustains a particular model. Thus, when using a Baradian approach to understand the archaeological record, viewing archaeological methods and practices in terms of 'following' becomes problematic.

\section{Post-Cartesian thinking}

Barad's agential realism theory rejects the idea that causes lead to effects, it also disputes the idea that causes are external forces $(2007,214 ; 2012)$. Thus, 'following' is incongruous to an agential realist framework. Of equal importance is the problem that 'following' articulates a universal human body with definite contours, and this is rooted in a Cartesian dualism that I am keen to move beyond (see Barad 2003, Govier 2016, 2017, in press, Attala 2017, Attala and Steel in press). A Baradian approach highlights that the analyst is entrenched in the 'knowledge getting' (see Kolb 2015, 38) processes that inform the production of the event (Barad 2007, 48-49). Thus, the act of 'following' is problematic as it creates a formal break between the archaeologist and the past, and also neutralizes their role in the formation of 
knowledge (on representationalism see Barad 2007, 48-49, Anderson and Harrison 2012, 14-15, 19). From a Baradian perspective, archaeologists do not simply follow matter, nor is matter as clearly removed, separate, or apart from archaeologists as implied by the act (see Barad 2003, 2007; DeLanda 2006; Bennett 2010; Coole and Frost 2010).

\section{'In between' or following}

I propose that archaeologist Lambros Malafouris has the potential to remediate the issue of 'following' via his examination of the 'in between' humans and matter (2008c). Malfouris challenges mind-body dualism through the neuro-scientific analysis of material interactions. Using the relationship formed between the potter and clay, he examines the 'in between, rather than within, persons and things' and describes this as the 'brain-artefact interface' $(2008 \mathrm{c}, 20,22)$. Malafouris $(2013,236)$ focuses on the hylonoetic ('thinking through and with matter'), and presents the concept as an alternative to hylomorphism, a model which is often conceived as a process where the potential object is formed in the internal mind and then projected onto materials (Ingold 2013, 21). The problem with hylomorphism is that it is blatantly anthropocentric (and, crucially, inaccurate) to assume that humans (categorically and consistently) impose form onto 'passive' matter (see Ingold 2013, 21; Malafouris 2014, 145). Equally, externalist approaches to the mind contend we think through things, and not necessarily before making things, which leads to a causal issue-put simply, hylomorphism suggests the idea comes first and the making comes second (again, a linear causal relationship is envisaged) (on hylomorphism see Malafouris 2014, 152).

Malafouris' approach clearly addresses the hylomorphic predicament by adapting the causality of the emergence; for Malafouris, the focus is on the creative idea-an inseparable mind matter moment-which he describes as 'a dialectical formation in action' $(2014,145)$. Thus, the potter at the wheel touching clay is conceived as a 'hylonoetic space' $(2014,145)$. Whilst Malfouris' ideas problematise Cartesian binaries, 
and in-terms of 'inseparability' resonates with agential realism; intuitively, I would not describe a Baradian phenomena as a dialectic formation.

In archaeology, dialectics is often used informally to mean " inextricably intertwined," "mutually constitutive," or simply “interdependent”" (Marquardt 1992, 103); I believe Malafouris envisages this type of relationship between mind and matter. Marquardt illustrates the complexity of the term and how it 'can be employed as a worldview, a method of inquiry, and a medium of exposition' $(1992,102)$. In philosophy, whilst there are important nuances in the dialectics discourse, it is clear that Hegelian dialectics involves opposing sides, and a linear progression is achieved through dialogue (see Maybee 2016). Archaeologists Webmoor and Witmore have highlighted the failings of such an approach, describing dialectics as 'the impoverished logic of contradiction'; and arguing that characterising the relationship between humans and things as dialectical 'is to begin with a particular, asymmetrical bifurcation of the world' $(2008,54,57)$. By proposing tension between two interacting forces, dialectics (in the formal sense) tends to indicate a linear causal chronology. Additionally, a further issue with dialectics is that it is tied to ideas about progression (on 'progressive momentum' and dialectics, see Webmoor and Witmore 2008, 58). In response to this problem it is worth noting that Barad $(2012,50)$ offers a 'diffractive' methodology which entails looking for 'the patterns of difference that make a difference', and this analytical method resonates with broader anthropological (and archaeological) concerns regarding difference, multi-perspectivism and cultural relativism. Thus, the analyst is always entrenched in the knowledge getting process; the archaeologist is embedded in the 'chronoarchitecture' (Malafouris 2008c, 26) of the archaeological event. Malafouris clearly evidences mind-matter moments that challenge the binary implied through the act of 'following', however, the dialectical relationship he evokes remains problematic from a Baradian perspective. Dialectical thinking begins with the assumption that there are unique entities, and Barad contests this point by arguing things are 'in-phenomena' $(2003,815)$. This incongruity suggests that Barad's theory offers something different. 


\section{Matter-discourse-movement}

Agential realism offers a conceptual framework that recognises how discourses and material conditions inform the materialization of matter-action (phenomena) (Barad 2007, 34). A vital aspect of agential realism (and a key reason why it is bracketed within the New Materialisms turn) is that matter plays a crucial part in the process (Barad 2012, 170), therefore causality emerges from the intraaction of matter, discourse, and movement (cf. Marshall and Alberti 2014, 26). If we think of the potter at the wheel, whilst making, the body moves and makes shapes and forms that correspond with the materials 'in-phenomena'; the material's properties and capacities also inform the making event and the agency that emerges from the enactment (Barad 2003, 827; Govier 2017). According to Barad, the body as material 'plays an active role in the workings of power' and she contends that the regulatory practices in action are 'fully implicated in the dynamics of intra-activity' (Barad 2003, 809, 822). Crucially, there is no 'a priori division between matter and meaning' (Marshall and Alberti 2014, 22). For archaeologists, this means that the discourses that shape and inform our interpretations impact on the archaeological materials we analyse, equally, these materials are not passive, but similarly inform the emergence of the archaeological record (or phenomena). Barad highlights the act of measuring and how measuring produces 'determinate boundaries'; therefore, by creating 'cuts' and observing 'things' the archaeologist is in-phenomena with the archaeological record; thus, archaeologists are 'with'-not 'following'-the material (2012, 62; 2007 , 175; see Ingold 2017b, 13; for further discussion of Barad's theory see Marshall and Alberti 2014; Govier 2017, in press).

\section{Conclusion}

Reflecting on the nuances between causal models can help us locate the type of analytical method we wish to employ when interpreting material events in the archaeological record. From a Baradian perspective, the analysis of phenomena entails the consideration of matter, discourse, and movement; therefore, there is a dynamic between matter (the properties and capacities of the matter), discourse (the 
culture-specific movements of the doing), and action (the creative knowledge transmitted during the correspondence between matter) (cf. Marshall and Alberti 2014, 26). In recent publications, particularly in his work on 'correspondence-thinking', Ingold seems to move away from 'following' and towards 'togethering' $(2017 \mathrm{~b}, 41)$; I contend that this subtle change marks a notable shift in his thinking. In this paper I have argued that Barad's agential realism offers a new way of thinking about material engagement. The intention behind this provocation is not to diminish the rich data that can be achieved through following, rather, it is to problematise the act for those who subscribe to post-Cartesian thinking. I contend that Barad's reconfiguration of causality is important for archaeologists. If, according to Barad, ontology is not predetermined but shape-shifts depending on the apparatus used to make the measurement, then the 'ontological gap'-that causal flow-is collapsed, and everything is in the 'doing' (see Marshall and Alberti 2014, 26). To end this article, I embrace the spirit of the provocateur and finish with a question that reads a little like a riddle: when it comes to archaeological interpretation do you 'follow' the material or are you 'in between', and even if you are 'in between'-are you still following?

\section{Acknowledgements}

My work is clearly influenced by Karen Barad, Tim Ingold and Lambros Malafouris; I am grateful for the continued inspiration their works provide. Early drafts of this paper were first shared at TAG 2017 and the EAA 2018. I would like to thank Oliver Harris for reading a draft of this paper and offering insightful comments. I also wish to thank the vibrant research community at University of Wales Trinity Saint David (Lampeter), particularly Louise Steel. This paper is the result of my own research, thus the usual disclaimers apply.

\section{References}


Anderson, B., and P. Harrison, 2010: 'The promise of non-representational theories'. In B. Anderson and P. Harrison (eds), 2012. Taking-place: Non-representational theories and geography. Farnham: Ashgate. $1-36$.

Attala, L., 2017: “"The Edibility Approach”: Using Edibility to Explore Relationships, Plant Agency and the Porosity of Species' Boundaries'. Advances in Anthropology. 7(3): 125-145.

Attala, L., and L. Steel. in press: 'Introduction'. In L. Attala and L. Steel (eds), Body Matters: Exploring the materiality of the human body. Cardiff: University of Wales Press.

Barad, K., 2000: 'Reconceiving scientific literacy as agential literacy, or learning how to intra-act responsibly within the world'. In: S. Traweek and R. Reid (eds.), Doing science + culture. New York: Routledge. 221-258.

Barad, K., 2003: 'Posthumanist Performativity: Toward an Understanding of How Matter Comes to Matter'. Signs: Journal of Women in Culture and Society. 28(3). 801-831.

Barad, K., 2007: Meeting the Universe Halfway: Quantum Physics and the Entanglement of Matter and Meaning. Durham: Duke University Press.

Barad, K., 2012: 'Matter feels, converses, suffers, desires, yearns and remembers'. In: R. Dolphijn and I. Tuin, New Materialism: Interviews \& Cartographies. Michigan: Michigan Publishing and London: Open Humanities Press. 48-70.

Bennett, J., 2010: Vibrant Matter: A Political Ecology of Things. Durham, North Carolina: Duke University Press.

Coole, D., and S. Frost, 2010: 'Introduction'. In D. Coole and S. Frost (eds), New Materialisms: Ontology, agency, and politics. Durham, NC and London, 1-43.

DeLanda, M., 2006: A New Philosophy of Society: Assemblage Theory and Social Complexity. London; New York, NY: Continuum.

Deleuze, G. and Guattari, F., 2005 [1980]: A Thousand Plateaus. Minneapolis, MN: University of

Minnesota Press.

Edgeworth, M., 2012: 'Follow the Cut, Follow the Rhythm, Follow the Material'. Norwegian Archaeological Review. 45(1). 76-92.

Gell, A., 1998: Art and Agency: An Anthropological Theory. Oxford: Clarendon Press.

Govier, E., 2016. 'The Cartesian Cut? Exhibition catalogue'. [online] Available at: $<$ https:// issuu.com/ eloisegovier/docs/cartesian_cut_exhibition_catalogue> accessed 9.11.18.

Govier, E., 2017: Creative practice: How communities were made at Çatalhöyük. Unpublished PhD Thesis, University of Wales.

Govier, E., in press: 'Bodies that co-create: The residues and intimacies of vital materials', in L. Attala and L. Steel (eds), Body matters: Exploring the materiality of the human body, Cardiff: University of Wales Press. 
Govier, E. in press: 'The Coal beds of Generations X, Y, and Z: Syncing, Learning and Propagating in the Age of the Posthuman'. Journal of Posthuman Studies: Philosophy, Technology, Media. 2(2): 147-165.

Ingold, T. 2007. Lines a Brief History. Oxon: Routledge.

Ingold. T., 2013: Making: Anthropology, Archaeology, Art and Architecture. Oxon: Routledge.

Ingold, T., 2017a: 'On Human Correspondence'. The Journal of the Royal Anthropological Institute. 23 (1). 9-27.

Ingold, T., 2017b: Correspondences. [online] Available at: $<$ https://knowingfromtheinside.org/files/ correspondences.pdf $>$ accessed 29.1.19.

Kersel, M. M. and Chesson, M. S. n.d. Follow the Pots Project. [online] Available at: $<\underline{\text { http:// }}$ followthepotsproject.org/> accessed 19.1.19.

Kolb, D. 2015. Experiential Learning: Experience as the Source of Learning and Development. NJ: Pearson Education, Ltd.

Malafouris L., 2008a: 'Beads for a plastic mind: the 'blind man's stick' (BMS) hypothesis and the active nature of material culture'. Cambridge Archaeological Journal. 18(3). 401-14.

Malafouris, L., 2008b: 'Is it 'me' or is it 'mine'? The Mycenaean sword as a body-part'. In: J. Robb and D. Boric (eds), Past Bodies. Oxford: Oxbow Books. [online] Available at <http://cogprints.org/ 6432/1/ Malafouris.ch12.PastBodies.pdf $>$ accessed 13.1.17.

Malafouris, L., 2008c: 'At the potter's wheel: an argument for material agency'. In: C. Knappett and L. Malafouris (eds.) Material Agency: Towards a Non-anthropocentric Perspective. New York,

NY: Springer. 19-36.

Malafouris, L., 2013: How things shape the mind: a theory of material engagement. Cambridge, MA: MIT Press.

Malafouris, L., 2014: 'Creative thinging: The feeling of and for clay'. Pragmatics \& Cognition. 22 (1). pp.140-158.

Marquardt, W. H. 1992. 'Dialectical Archaeology'. Archaeological Method and Theory

4. 101-140.

Marshall, Y., and B. Alberti., 2014: 'A matter of difference: Karen Barad, ontology, and archaeological bodies'. Cambridge Archaeological Journal. 24(1). 19-36.

Maybee, J. E., 2016: 'Hegel's Dialectics'. In: The Stanford Encyclopedia of Philosophy (Winter 2016 Edition), E. N. Zalta (ed.). [online] Available at: <https://plato.stanford.edu/archives/win2016/ entries/ hegel-dialectics/> accessed 31.10.18.

Oxford Dictionaries, 2018. English Oxford Living Dictionaries. Oxford University Press. [online] Available at: $<$ https://en.oxforddictionaries.com/> accessed 12.12.18. 
Webmoor, T., and C. L. Witmore., 2008: 'Things Are Us! A Commentary on Human/ Things Relations under the Banner of a 'Social' Archaeology'. Norwegian Archaeological Review. 41(1). 53-70.

Weismantel, M., and L. Meskell., 2014. 'Substances: 'Following the material' through two prehistoric cases’. Journal of Material Culture. 19(3): 233-251.

Witmore, C., 2014: 'Archaeology and the New Materialisms'. Journal of Contemporary Archaeology. 1 (2). 203-246.

\section{Biographical note}

Eloise Govier, MA, MLitt (St Andrews) PhD (Archaeology, Wales), is an artist conducting practiceled research in the fields of anthropology, archaeology and pedagogy. Her work has been exhibited internationally, and her research interests focus on material interactions in the past and present. She lectures in anthropology and archaeology at the University of Wales Trinity Saint David (Lampeter) and is a Fellow of the Higher Education Academy. 